\title{
Emerging Threats to Liberal Values
}

\author{
Albertus J Meintjes ${ }^{1}$ \\ ${ }^{1}$ Bachelor of Arts, South Africa \\ Correspondence: Albertus J Meintjes, 14 Katherine Close, Ballito, 4420, KZN, South Africa.
}

Received: August 4, 2018

Accepted: September 4, 2018

Available online: September 5, 2018

doi:10.11114/ijsss.v6i9.3518

URL: https://doi.org/10.11114/ijsss.v6i9.3518

\begin{abstract}
The values of individual security and the responsibilities of states as laid down in the 1994 UNDP human development report have changed the face of social and political interactions in the $21^{\text {st }}$ century, as liberal movements and shared norms pave the way for understanding while diplomacy and economic development keep the peace. These new liberal values have created a new paradigm that establishes the needs of the individual as a basis for peace. However, threats have emerged to challenge this new paradigm. These threats range from emerging populist leaders to the rigid nature of bureaucratic institutions unable to shift along with developing social and political norms. This paper examines the importance this new liberal paradigm and its link to human security, theorising why human security has become an important concept in political theory and real politick, and examines why the threats are a dangerous precedent.
\end{abstract}

Keywords: liberal values, human security, United States, diplomacy

\section{Introduction}

The $21^{\text {st }}$ century has the potential to be a watershed moment in the political history of mankind, with liberal values, human security concerns, and the individual, social security, migrants, Diasporas and the responsibility to protect becoming terms synonymous with global governance. Developed technology allows anyone to look into the heart of conflict and despair and understand the tragedy of political and social collapse. Africa and the Middle East are no longer news articles to be brushed over, and using the looking glass of social media, the entire world could far better see and understand humanitarian crisis. Advancing political concepts championing the right of the individual over the state, making the state the tool of the individual and removing the role of the individual as a cog in the state, meant that not only were social values for all classes in society improving, but petty dictators and warlords had a clear message from the rest of the world: do not cross the line of human rights violations. Diplomatic efforts and the emerging power of non-state actors in a post globalist society led to quite possibly the most peaceful era of history in human existence. Complex questions such as the state of Iran and nuclear proliferation solved through words and trust rather than conflict paved the way for future peaceful initiatives.

Despite all the potential of the $21^{\text {st }}$ century, recent political and public trends have seen an increase in support for right wing politicians and groups. Strong words and power politics, a rising support of conservative and fundamentalist ideals in the west and diplomatic failures are all signs that the liberal paradigm constructed in the past 18 years has come under fire. This paper aims to discuss the current standing of liberal ideals such as Human Security (HS), and how the current geopolitical climate is shifting towards the $20^{\text {th }}$ century climate of ideology, power politics and elitism.

Within political theory, the ultimate conflict is between the right and left spectrums of political thought. As such it is important to argue why liberal values and the accompanying theory here, HS, is so important to maintain. As such, the first section will explore the role the new liberal paradigm has in the world, and how human security theory has become an important companion theory to liberal thought and peace development. Second, the paper will explore the recent slide into cold war style power politics and pre Great War opaque diplomacy, focusing on western powers, such as president Trump and the EU, as well as disruptive elements facing liberal transformative values in the arenas of political, social and economic thought, and explore the danger they pose to the growing liberal traditions seen the world. Finally, the paper will examine a few reasons why the slide is happening now, and how it affects liberal values.

\section{The New Liberal Paradigm and Human Security}

When discussing the new liberal paradigm that has been established, it's important to define exactly what that means. As societies increased in social awareness and international politics shifted to prioritise the individual, a shift was seen. 
Social demonstrations encompassing movements such as gender inequality, humanitarian needs and the power of the one per cent shaped liberal thought and value into what we see today. Connected to this new liberal paradigm is the theory of HS.

HS is often critiqued for its values, critics focusing on it wide scope, stating that as a theory it is simply too vague to be used as a toolbox for political theory. (Paris, 2015) This paper takes the stance that the reified facet of wide ranging, real human needs has become an important cornerstone of maintaining peace. People on a global scale see conflict as a disruptive influence, and the question of how we may live together peacefully is seen as a question of value rather than rationality, with a focus on global moral science as Booth laid out. (Booth 1995, p. 109) In addition, HS as a theory is able to describe $21^{\text {st }}$ century threats and facets better than traditional theories such as realism is able to, a sentiment that Stephen James voices when examining key drivers of HS in the $21^{\text {st }}$ century (James, 2011) and as a basis for global interactions is able to spread peace and security better than realist goals are able.

There are signs that the HS is becoming more than simply a theory, as key components of HS thought become a reality. As Franceshet pointed out on his discourse on legality and HS, HS expanded security beyond that of the fundamental state and HS links together the previously incompatible sovereignty and human rights, by holding the state responsible for the human rights of individuals in the state. (Franceschet 2005, p. 10) Franceschet's initial comment on how HS expands the scope of international security beyond the state is particularly interesting given the relative global stability of the 2000's. Conflict is down, liberal values are up. Capitalism and democracy have removed the need for desperate land grabs, and shifted traditional realist thought into a new realm, where modern warfare is incredibly expensive and disruptive, shifting the cost benefit ratio of any territorial desires, as defensive realists like Kenneth Waltz argue. (Waltz 1979) Arguably, the cost of modern arms and the power of even conventional arms have increased the cost of expansion even further. Warfare between developed states and alliances becomes far too costly when a 6 million dollar MBT can be destroyed by advanced shoulder mounted munitions such as a Javelin missile at a fraction of the price.

Following the writings of Franceshet and James' on HS, it is possible to argue that HS should be the premier theory for securing peace in a complex $21^{\text {st }}$ century. James argues that HS challenges traditional paradigms by challenging realist arguments directly. We know that the absolute power of states is an illusion, and if it was true at one point, a globalised capitalist society running on alongside increasingly powerful non state actors has eroded the power of the state. (James 2011) This statement is important, as HS does not challenge that states are obsolete, but only that they are no longer the primary objective of policy.

Linking these changes to Franceschet's views of legitimacy and HS, new liberal norms have changed the focus of the traditionally state centric stage of global legalism, a sentiment that James shares. However, Franceshet goes further by stating that this move has resulted in the expansion of traditional, conventional limits of security beyond the state, where focus is no longer on territorial integrity, further widening the gap of nation state

By examining the writing of Franceshet and James', and applying these ideas to the societal changes and expectations we have seen, there is a linkage here that has the potential to create a new theoretical narrative. The shift in sovereignty and human rights and the change in territorial integrity support HS scholars who believe human security is critical for global peace (Franceschet, 2005, p. 10). Traditionally, scarcity of resources has led to conflict, however, it is not the state that requires resources, but the individuals inside of them. Following constructivist thought, a nation state is merely a construction of mutual goals. (Finkel 2016) A nation has no desires or needs, but the people that make them up do. If the individuals in a state are free from want and fear, there is no scarcity that the state would need to fill and thus, no need for aggressive strategies. Advanced sustainable technology, the erosion of traditional economic border the rise of e commerce and transnational corporations are all examples of the advanced economy that states no longer have a hand in (James 2011). While global politics are rarely so simple, the idea itself is an attractive and one that seems to be holding in the current geo political climate due to sound transparent diplomacy, global governance and free market trading. Transparent and open diplomatic relations provide these opportunities for free trade and minimise the chance for corruption by both individuals and corporations that may seek to capitalise of agreements at the expense of the individual.

If the previous assumption has been established that human security is a major boon to the state of world peace and a viable method to continue peace by securing individual rights, then it would be logical to assume that human security and liberal global values as a means to secure peace should be protected at all costs. However, since 2015 the world has seen a steady decline of liberal values in favour of more conservative and nationalistic endeavours. In terms of global, macro politics, human security is not damaged by food or medical insecurity, but by a focus on the state rather than the individual. A backtrack to the conservative ideals of the $20^{\text {th }}$ century is the most damaging possible occurrence for HS, and the increasing signs of primoridialist nationalist thought and anti-socialist sentiments are damaging to the fabric of global liberal values that have taken root.

The strings of James' argument on the eroding power of the state in a shifting economic world, and Franceshet's views on 
the expansion of individual security concerns due to the erosion of traditional, realist concerns, we arrive at a place where HS is a theory that not only encapsulates the current global arena, but also potentially acts as a way forward for peaceful development. If scarcity of resources is no longer a primary concern due to globalised economic structures and diplomatic missions, where states politely request each other to increase production of resources rather than use gunboat diplomacy, as seen in western interactions in the middle east (Ford 2018), we know HS becomes a premier theory to spread peace in the world, where the spread of humanitarian values and norms transcend ethical concerns of what we should do in view of the 1994 UNDP statement, to what we must do to ensure peaceful global interaction.

Despite these developments, a surge in right wing politics and public groups is a sudden anomaly that requires analysis. The following section will examine why this surge is happening and why it is a dangerous development.

\section{The Slide}

No other event has provided more evidence to point to a slide back into power politics than the presidency of Donald Trump. President Trump is not entirely to blame for the return of power politics, but his presidency has revealed a darker layer to global politics than media and diplomats would show us. The actions of the US commander in chief provide an excellent opportunity to examine the new liberal paradigm versus realism and power politics.

Trump marks an interesting case study for political theorists. His rise and popularity has been analysed many times, and doesn't bear repeating, the popular consensus being that Trump represented the potential for change to the masses who were disillusioned with rapid development and the growing disdain for dirty industry (Paterson and Frazier 2017). The rhetoric during his campaign smacked of revisionist, near socialist talk. He appealed to coal miners and the low income part of the US population to trust in his vision for a return to traditional American values and a growth in jobs and the economy. I have little doubt that Trump genuinely believed in his own message and vision for America. However, despite his appeal to the grassroots of America, his style of elitism and cold war style diplomacy is at ideological odds with his original message. This picture of the man affects the following section, as the purpose of this paper is not to analyse all of Trump's domestic policies, but his global policies and diplomatic decisions. From his initial cold, militant stance towards North Korea, to his hostility towards allies, Trump has proven himself to be a man that does not respect a measured approach and prefers force and power over traditional interstate diplomacy.

I postulate that this move by the primary global actor is a shift back towards the style of elitist diplomacy seen pre-world war one. While Trumps overly forceful manner and threats would hardly suit that era well, Trump is a leader who prefers to conduct diplomacy privately, in one to one meetings with North Korean leader Kim Jong Un and Russian Oligarch Vladimir Putin. Most recently, when Trump met with Putin privately in Helsinki, the media and opposition voiced their concern and alarm for the privately conducted diplomatic meetings, and with good reason. The general sentiment towards negotiation and diplomacy following the great war was that opaque, private diplomacy deciding the fate of millions in a state was seen has fundamentally unethical and improper. Trump is unknowingly repeating the mistakes of the past, and unfortunately, seems to lack the political or historical knowledge to realize why his error is so potentially dangerous. Any move that focuses on the power of states and, even worse, the elites in those states while moving away from the welfare and knowledge of the individual could threaten the new stance focused on human security in the $21^{\text {st }}$ century. The style of diplomacy being practiced here is a direct threat to not only the established political etiquette of modern diplomacy, but also liberal norms. Opaque diplomacy is in direct contradiction to transparency that democratic society idealise, and lead to elite members of society making decisions with no official oversight. Furthermore, as demonstrated with North Korea, private meetings have no guarantees and give breathing room to regimes with no track record in maintaining promises.

The move towards opaque diplomacy should be concerning for political scientists the world over. In 2004 writing on the danger of elite and private diplomacy conducted in the foreign offices before the outbreak of the Great War, Otte pointed out that old and secret diplomacy was seen as a major factor for the outbreak of war. (Otte 2004) In 2010, Bernard E Brown, not writing for HS perspectives, but purely from diplomatic concerns started his paper with the words, "The era of sovereign states is dead". (Brown 2001) Brown himself saw the change in economy and interstate diplomacy in the shifting global world to be indicative of changes yet to come. Trump's move towards personal diplomacy with oligarchs and dictators is simply not an encouraging sign. His attitude speaks of an elitist mind-set that focuses on individual leaders of states, rather than concern with the individual security of civilians. Why this shift is occurring now is up for debate, whether critics believe it to be a facet of Trump's personality, or a necessity of dealing with those leaders that still reject the global shift to liberal norms is not the purpose here, but suffice to say that a move towards power politics and elite diplomacy is a troubling one.

However, Trump's power politics and policies are not the only example of right wing nationalist parties and proponents. Nationalism at its core is a primoridialist concept, (Finkel 2016) That is, one that focuses on the ethnicity and culture of one's own people over others. As stated in the section on the new liberal paradigm, the traditional views of nation states 
and sovereignty have shifted, with the individual becoming the referent actor, and as such rising nationalist sentiment is a direct threat to the new liberal norms. While we have seen a rise in the nationalist sentiment in the US, in racially charged and xenophobic gatherings, an equally worrying trend is the growth of nationalism Europe. Similar to Europe, recent hits taken by liberal parties have been linked to the large diaspora from Syria. The large number of refugees saw a bloom of xenophobic violence, and thus nationalist sentiments. The liberal norms and values discussed earlier are not conducive to nationalist sentiment, due to the value placed on the individual. Likewise, nationalist right wing sentiment does not match HS theory due to the focus on the state, rather than the individual.

In Europe, the move towards nationalist sentiment is troubling and can be seen in the states of Hungary and Poland in particular. Poland is a particularly interesting case study, as it has linkages to similar occurrences in the US. Phillip Swallow wrote that with a high economic growth in 2017, one may have expected more support for centre parties, (Swallow 2018) and it certainly wouldn't make sense to vote against the system that brings economic growth.

However, with the economic growth came the collapse of heavy industry, which led to maligned groups and the needs of these groups outside of the economic growth unfulfilled. Swallow believes that by joining the EU, institutions of the state were locked in, giving the state a rigidity that shaped political and economic institutions in the coming years. These rigid institutions combined with economic changes and a maligned sector provided fertile ground for dissatisfaction and populism. (Swallow 2018)

Most recently, Germany has also seen a surge in right wing supporters following the diasporas of the Middle East. Large protests have been held in Chemnitz in response to the arrest of an Iraqi and a Syrian on charges of murder after they stabbed a local man to death. The ensuing protests have seen Nazi salutes and large gatherings of right wing supporters. (Washington Post 2018) Xenophobic movements such as these are often fuelled by false information, and prey upon the "other". This sort of movement is typically harmful to liberal values not just for its harmful rhetoric, but also the effect on other's individual security. If a group of individuals are privileged, it will inevitably lead to a group being seen as "inferior". Chemnitz itself is in Eastern Germany, and there exists a linkage here that is similar to Poland. Eastern Germany has had traditionally lower wealth than Western Germany due to the historical effects of the USSR occupation. These lower income groups in Eastern Germany face similar problems to Poland in that a group of individuals have been left behind in the development of the nation at large. The liberal norms in the Western portion failed those in the East, and this delivery failure has led to growing support for right wing values.

By following the stories of each state, a common narrative emerges. Disillusioned masses who were left behind during economic and political advancement and lived in the fringe areas of states were lending their votes to the right wing, conservative politicians. By failing to ensure the human security needs of these people were met, their uncertainty led them to right wing politicians, and in turn created a threat to liberal values and norms. Ironically, a move towards nationalist values due to dissatisfaction is unlikely to secure people's needs and security as nationalism focuses on the state first, securing media sources and legal representation to control the narrative of those in power.

\section{The Decline of Liberal Values}

While this paper has discussed the relevance of HS in the $21^{\text {st }}$ century as well as the rise of old ideals of nationalism and populism and a correlation does seem likely, the nature of the causal relationship between HS and the counter influences of nationalism and old school diplomacy is not certain. Put simply, has nationalism and the rise of increasingly populist politicians led to a decline in HS, or vice versa?

At the outset, one is tempted to pass the blame to the rise of nationalism and populist leaders. Leaders like Trump and Poland's Duda have a detrimental effect of liberty and human security. In America, conservative laws and views malign individual liberties and by extension security, while in Poland, the threat of government control on liberties grows ever higher. Leaders like Trump inadvertently affect global politics by favouring the old school power politics as mentioned earlier.

Looking at the evidence presented, it seems clear that the decline of HS is a result of emerging nationalist, right wing values due to a disillusioned and maligned group. However, the support for the right wing often stems from the forgotten masses, and as the case of Poland, this seems to be the cycle. An era of peace and prosperity typically only favours a section of society, while the broad maligned base will rally against liberal values, once it is clear those values do not benefit them. HS and liberal values are powerful, but difficult to reify in policy decisions.

Worryingly, the distribution of prosperity follows its own rules, and the laws of the free market are rarely affected by the government, certainly not the traditionally laissez faire US, or Poland's rigid structure are set up to deal with disparity and inequality. Perhaps there is a lesson to be learnt about HS here. While the HS theory hold traction and application of Owen's threshold based idea for the value of different security areas based on the importance and need at the time is valuable, humans are still beholden to want more. The absolute basic human security requirements may be met for fringe 
maligned groups in the US and Poland, but that doesn't mean they don't aspire for more. People typically don't want to survive, they want to thrive. And while bureaucratic institutions may be aware of the problem, they don't have the structural means to address it in the framework of traditional bureaucracy.

HS requires the force of a state mandate behind it, even if that mandate is recognition of a problem and appeal for a solution. A solution for those individuals supporting right wing politics maligned due to economic insecurity would be retraining in more modern and demanding positions. But who would mandate such a move? Private companies have the means to provide the training and positions, but the population that requires this is often out of the way of major population centres. In the US for example, the laissez faire style of governance also means that mobilising state level resources for training in future professions is not a viable option. The conflict between human security, economic concerns, rigid bureaucracy and government are all interlinked, affecting the growth of the individual and contributing to a cycle of rising nationalist right wing tendencies, before the reality of right wing politics and priorities set in, and liberal values once again take hold.

\title{
5. Conclusion
}

Liberal values and concern for the individual in the incredibly complex $21^{\text {st }}$ century has undoubtedly reinforced peace. There is finally a theoretical rationale behind ethical concern that goes beyond self-interest and survival that sees the well-being of others as a driver for peace. However, the rise of the values is still challenged by the maligned groups who have not benefitted from economic growth, or have been left behind by development. The systems that are in place are simply not built to support a focus on wide ranging individual needs in states such as the US.

It would appear that the rise of right wing ideals is a more complex issues that at first glance. There appears to be a cycle to these values, and we may well be at the end of it. A cycle which begins at the growth of liberal ideals and values moves to aspirations of equality and benign government. The inevitable economic slumps (or disparate growth) lead to economic and political uncertainty in the fringe, leading to a rise of nationalist sentiment. Nationalist control and focus of the state takes place, which traditionally has had deleterious effects to global peace as a more aggressive stance is taken to assert dominance on the global stage. Hopefully the next step in the cycle is a return to liberal values, as liberal values and desire for personal freedoms take hold again.

Economic disparity causing political tension isn't a new phenomenon, but the draw maligned groups have towards right wing politicians is a result of the new liberal paradigm in recent years. This means that the problem with liberal values is that it is not inclusive enough. By pairing human security to liberal values we can see the importance of individual security, and a better means to make it a reality.

These returning old paradigms are a threat to the values and norms of liberal norms and HS, which are not able to operate alongside right wing, nationalist agendas. HS has become a valuable part of our global norms and values, but there is clearly a problem with the implementation that swings opinion back to nationalist and right wing ideals. Governance and economic concerns must support implementation of HS and liberal values, and this is a field that deserves more attention and research to avoid an impotent potential political cycle. Respect for the needs of the individual in one's own state as well as others must be realised.

Care should be taken not to support emerging leaders who offer quick solutions and a return to strong traditions and values of a bygone age. These leaders offer a placebo for real afflictions, and their solutions are rooted in a world that simply no longer exists. They are not in the business of changing the lot of the individual in a manner that is conducive to long term change.

\begin{abstract}
About the Author
Albertus Jacobus Meintjes was awarded a B.A in International Studies at the University of Stellenbosch where he also completed his Honours in Political Science. He later received a M.A in International Security from the University of Leicester. He has worked professionally in the Middle East and Asia and operates as an associate analyst for a private intelligence firm.
\end{abstract}

\section{References}

Booth, K. (1995). Human Wrongs and International Relations. International Affairs, 71, 103-126.

Brown, B. (2001). What Is the New Diplomacy?, American Foreign Policy Interests, 23, 3-21.

Finkel, M. (2016). "Theories of Nationalism: A Brief Comparison of Realist and Constructivist Ideas of the Nation." Inquiries Journal, 8(10). Retrieved from http://www.inquiriesjournal.com/a?id=1460

Ford, P. (2018). Syria in the Crosshairs of Gunboat Diplomacy. Middle East Eye. Retrieved from https://www.middleeasteye.net/columns/syria-new-era-gunboat-diplomacy-834414315 
Franceschet, A. (2005). The Politics of Global Legalism and Human Security, Policy and Society, 24(1), 1-23.

James, S. (2011). The Key Drivers of Human Security Discourse and the Challenge to Realism. Cornell International Affairs Review [Online], 4. Available: http://www.inquiriesjournal.com/a?id=1228

Otte, T. G. (2004). Old Diplomacy: Reflections on the Foreign Office before 1914. Contemporary British History 18, 31-52.

Paris, R. (2015). Human Security: Paradigm Shift or Hot Air? International Security, 26, 87-102.

Paterson, L., and R. Frazier, (2017). Coal Country Picked Trump. Now, It Wants Him To Keep His Promises. NPR. Retrieved from https://www.npr.org/2017/01/01/507693919/coal-country-picked-Trump-now-they-want-him-to-keep-his-promises

Swallow, P. S. (2018). "Explaining the Rise of Populism in Poland: The Post-Communist Transition as a Critical Juncture and Origin of Political Decay in Poland." Inquiries Journal, 10(07). Retrieved from http://www.inquiriesjournal.com/a?id=1740

The Washington Post. (2018). Rumors fueled far-right protest after killing in German city. The Washington Post, 2018, Retrieved from

https://www.washingtonpost.com/world/europe/rumors-fueled-far-right-protest-after-killing-in-german-city/2018/0 8/29/1ba54dfa-abac-11e8-9a7d-cd30504ff902_story.html?noredirect=on\&utm_term=.2a6758629f14

Waltz, K. N. (1979). Theory of international politics. Reading, Mass: Addison-Wesley Pub. Co.

\section{Copyrights}

Copyright for this article is retained by the author(s), with first publication rights granted to the journal.

This is an open-access article distributed under the terms and conditions of the Creative Commons Attribution license which permits unrestricted use, distribution, and reproduction in any medium, provided the original work is properly cited. 